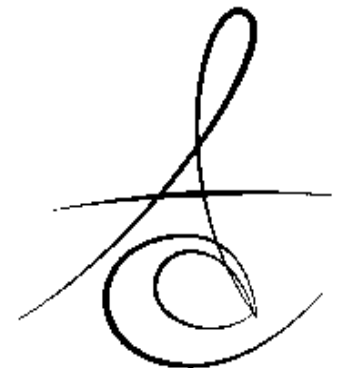

Makale Kodu/Article code: 1120

Makale Gönderilme tarihi: 15.03.2013

Kabul Tarihi; 30.04.2013

\section{DENTAL KÖK HÜCRELER VE SÜT DİŞLERİNİN KÖK HÜCRE ÇALIŞMALARINDAKİ ÖNEMİ}

\section{DENTAL STEM CELLS AND THE IMPORTANCE OF DECIDIOUS TEETH FOR STEM CELL STUDIES}

Dt. Gülcan ÜNSAL*

\author{
Dt. Özge ÖZMEKİK*
}

\section{ÖZET}

Kök hücreler sınırsız bölünebilme ve kendini yenileme özelliğine sahip, vücudumuzda doku ve organları oluşturan ana hücrelerdir. Kolay ulaşılabilmeleri ve minimal invaziv işlem gerektirmeleri nedeni ile dental kök hücreler postnatal kök hücre kaynakları arasında yerini almıştır. Dental pulpada, apikal papillada, periodontal ligamentte, dental folikülde ve süt dişinde multipotent kök hücreler izole edilmiştir. Düşen süt dişi kök hücrelerinin nöronlara, adipozitlere, kondrositlere, osteoblastlara ve odontoblastlara diferansiye olduğu tespit edilmiş, otolog kök hücre tabanlı tedavilerde alternatif kök hücre kaynağı oluşturabileceği bildirilmiştir.

Anahtar Kelimeler: Kök Hücre; süt dişi; mezenkim; multipotent

\section{GİRİş}

Teknolojideki ilerlemelere bağlı olarak sağlık alanında hızlı gelişmeler görülmektedir. İnsan hayat kalitesini ve süresini artırmak için bilim adamları hız kesmeden çalışmaktadırlar. Doğumsal veya sonradan edinilmiş organ ve doku hasarlarının iyileştirilmesi için doku ve organ nakilleri üzerine yoğunlaşılmış, bununla birlikte doku mühendisliği ve kök hücre kavramları ortaya çıkmıştır.

Vücudumuzda bütün doku ve organları oluşturan ana hücreler kök hücrelerdir. Kök hücre, fonksiyonel olarak farklılaşmamış ve heterojen üreme potansiyeli olan hücre olarak tanımlanmaktadır.

\section{ABSTRACT}

Stem cells are fundemental cells that have charecteristics of self-renewal and being divided unlimitedly, and generate tissue and organs. Dental stem cells have taken place among the postnatal stem cell sources as they are easy to get and require minimally invasive process. Multipotent stem cells in dental pulp, apical papilla, periodontal ligament, dental follicle and decidious teeth are isolated. It is determined that stem cells from human exfoliated decidious teeth differantiate to neurons, adipocytes, chondrocytes, osteoblasts and odontoblasts, and it is reported that they can be alternative stem cell source at autolog stem cell based therapy.

Key words: Stem cell; decidious teeth; mesenchyme; multipotent

Henüz farklılaşmamış olan bu hücreler sınırsız bölünebilme, kendini yenileme, organ ve dokulara dönüşebilme yeteneğine sahiptir. ${ }^{1}$

Kök hücre araştırmaları ilk defa 19. yüzyılda başlamıştır. 1950-60'ı yıllarda Prof.Dr. Süreyya Tahsin Aygün hayvanlarda fetal greft ve kordon kanı greftleri ile çeşitli hastalıklar üzerinde çalışmış, insan ömrünü uzatmanın yolunun, doğum sonrası atılan plasentalarda ve kordon kanı hücrelerinde olduğunu söylemiştir. ${ }^{2}$

1953 'te Leroy Stevens farelerin testis hücrelerinde teratom benzeri hücre tespit etmiştir. ${ }^{3}$ 1967 yılında tanımlanan embriyonel karsinoma hücrelerinin kültür ortamında çoğaltılması da bu alanda ileri doğru atılmış önemli bir adımdır ve o

\footnotetext{
*istanbul Üniversitesi Diş Hekimliği Fakültesi Pedodonti ABD
} 
tarihten buyana insan ve fare teratokarsinomlarından bir çok hücre serisi tanımlanmıştır. ${ }^{4}$

1997'de İskoçya'da Campell ve arkadaşları tarafından ilk memeli hayvan (koyun) kopyalanmıştır. 1998 yllında insan kopyalama üzerine çalışmalar başlatılmış, etik tartışmalara sebep olması nedeniyle bilim adamları çalışmalarına son vermişlerdir. ${ }^{5} 1998$ ylında ABD'li bilim adamı James Thomson ve ekibi, ilk defa "insan embriyonik kök hücrelerini" laboratuvarda embriyodan ayrıştııı çoğaltmışlardır. 2000 ylıına insan embriyonik kök hücresinin pluripotent olduğu anlaşılmıştır. ${ }^{(6)}$ Doku mühendisliği ve kök hücre çalışmaları, bu etik ve ahlaki sınırlamalar çerçevesinde hızla devam etmektedir.

Temelde kök hücre tanımını oluşturan prensipler şunlardır:

-Kendi kendini yenileyebilme ya da başlangıçtaki hücrenin karakterlerini taşıyan en az bir benzer hücre oluşturabilme yeteneği,

-Tek bir hücreden birden fazla seri hücrelere farklılaşabilme (diferansiyasyon),

-Belli bir dokunun in-vivo fonksiyonel rekonstrüksiyonu,

-Kendi kökeni dışında farklı dokulara ait hücrelere dönüşme (transdiferansiyasyon). ${ }^{4}$

Kök hücrelerin transdiferansiyasyon özellikleri çok ilgi uyandırsa da doku iyileştirmedeki etkileri göz ardı edilmemelidir. ${ }^{(1)}$ Kök hücre çalışmalarının alzheimer, sinir hasarları, lösemi, diyabet, kalp hastalıkları, kemik defektleri gibi sorunlara çözüm bulunacağı düşünülmektedir. ${ }^{5,7}$

\section{KÖK HÜCRE ÇEŞİTLERİ}

$\begin{array}{ll}\text { 1) } & \text { Totipotent Hücre } \\ \text { 2) } & \text { Pluripotent Hücre } \\ \text { 3) } & \text { Multipotent Hücre }\end{array}$

\section{Totipotent Hücre}

Sperm ile yumurtanın birleşmesinden sonra oluşan hücre (zigot) tek başına tüm organizmayı meydana getirebilecek genetik bilgiye ve güce sahiptir. Vücuttaki tüm hücrelere dönüşebilecek potansiyele sahip olan bu ilk embriyonel hücreye "totipotent" (her şeyi yapabilen) hücre denilmektedir. ${ }^{4,7}$

Döllenmeyi izleyen ilk dört ile beş gün içerisinde tek hücreden meydana gelen tüm hücreler aynı güce sahiptir ve bu hücreler rahim içerisine yerleştirildiğinde her biri tek başına bir organizma oluşturabilecek güçtedir. Erken embriyonik dönemde 4 hücreden 8 hücreye kadar olan tüm blastomerler totipotenttir. ${ }^{9}$

\section{Pluripotent Hücre}

5. günden, yani 2-3 hücre bölünmesinden sonra meydana gelen hücreler "blastosist" denilen küresel bir şekil almaktadırlar. ${ }^{2,5}$ Embriyoda blastosistin iç hücre kitlesindeki embriyoblastlara "pluripotent" hücre denilmektedir. ${ }^{8} \mathrm{Bu}$ kürenin içerisindeki hücreler vücuttaki tüm hücrelere dönüşebilecek potansiyele sahipler; ancak tek başlarına tüm organizmayı oluşturamazlar. Gerekli ortam sağlandığında bu hücreler endoderm, ektoderm ve mezodermden köken alan yaklaşık 250 farkı türde hücreye farklılaşabilmektedirler. ${ }^{9}$

\section{Multipotent Hücre}

Anne karnındaki organizmanın daha sonraki gelişim aşamalarında hücreler biraz daha özel görevlere sahip olmakta ve erişkin kök hücrelerine dönüşmektedirler. ${ }^{(1)}$ Bu erişkin kök hücreleri de belirli hücre türlerini meydana getirmektedir. Örneğin kan kök hücresi kemik iliğinde bulunmakta ve gerektiğinde beyaz kan hücreleri, kırmızı kan hücreleri ve kanın pıhtılaşmasında görev alan trombositlere dönüşmektedir. Aynı şekilde deri kök hücreleri de değişik deri hücrelerine dönüşebilmektedir. Biraz daha özelleşmiş olan bu kök hücrelere "multipotent" (çok yetili) hücre denilmektedir. ${ }^{1,2,7}$

Totipotent hücreler embriyonun erken evresindeki kök hücrelerdir. Pluripotent hücreler embriyonun blastosit evresinden itibaren ve fetusta bulunabilen hücrelerdir. Multipotent hücreler ise kordon kanı ve yetişkin kök hücreleridir. ${ }^{1,2,7,8,10}$

\section{Hücreler}

\section{Elde Edildikleri Kaynaklara Göre Kök}

1) Embriyonel Kök Hücreler

2) Fetal Kök Hücreler

3) Erişkin Kök Hücreleri 1,2,9-11

\section{Embriyonel Kök Hücreler}

İnsanı oluşturan ilk hücre olan zigot bölününerek her 36 saatte bir sayısını ikiye katlamaktadır ve ilk 4 gün içerisindeki hücrelerin her biri tek başına bir insan oluşturabilecek potansiyele sahiptir. Bu erken dönemdeki hücrelere embriyonel 
kök hücreler denilmektedir ve totipotent özellik taşımaktadır. Anne karnındaki gelişimin 5'inci günlerinde oluşan hücre topluluğuna blastosist adı verilir ve bu hücre kümesinin iç kısmındaki hücrelerden elde edilen hücrelerin her birine de embriyonel kök hücre denilmektedir ve bu hücreler de pluripotent özellik taşımaktadır. ${ }^{10}$ Embriyonel kök hücreler in vitro olarak bütün somatik hücrelere dönüşebilme yeteneği sahiptirler. Bu hücreler tek başlarına insan oluşturamamakta ama insan vücudunda 200'den fazla sayıda değişik hücre türlerine dönüşebilmektedir. ${ }^{1,2}$

Embriyonel kök hücreler sınırsız olarak çoğalabilme kabiliyetlerinden dolayı diyabet, miyokart enfarktüsü ve parkinson gibi hemen hemen bütün dejeneratif ve hasar görmüş dokuların yenilenmesinde kullanılabilmektedir. Embriyonel kök hücreler, kendini yenileme ve farklılaşma için indüklendiklerinde özelleşmiş hücre türleri oluşturma potansiyeli ile rejenaratif tıp çalışmalarında ilgi odağı olmuştur. ${ }^{(8,11)}$ Ama bu hücrelerin kontrolsüz çoğalma ve tümör oluşturma potansiyelleri olduğu da unutulmamalıdır. ${ }^{(9)}$

Embriyonel kök hücreler genellikle tüp bebek ünitelerindeki fazla embriyolardan elde edilmektedir. Gebelik olursa ve aile başka çocuk istemiyorsa depolanmış olan embriyolar ailenin izni alınmak koşuluyla deneysel çalışmalarda kullanılmaktadır. Bu nedenle embriyonel kök hücreler ile çalışmalar etik sorunlarıda beraberinde getirmektedir. ${ }^{7-9,11-14}$

\section{Fetal Kök Hücreler}

Fetal kök hücreler abortuslardan veya çeşitli sakatlıklar nedeniyle gebeliğe son verilip alınan fetuslardan elde edilmektedir. Bu hücreler fetusun kan, kemik iliği, karaciğer ve böbrek gibi dokularından izole edilebilmektedir. Fetus kanı hematopoetik kök hücreden zengin bir kaynaktır ve buradaki hücreler kordon kanı ve yetişkin kemik iliğindeki kök hücrelere göre daha hızlı çoğalmaktadırlar. Fetal kök hücreler sınırsız sayıda bölünme ve kendilerini yenileme özelliğine sahiptirler ve bu hücrelerin genetik yapıları benzer özelliktedir. ${ }^{15}$

Fetustan elde edilen kök hücreler pluripotent yapıda olup gerekli koşullar sağlandığında kas, sinir, karaciğer gibi değişik hücre türlerine dönüşebilmektedirler. Fetal kök hücreler tekrar farklılaşarak kromozom sayılarını yarıya indirip yumurta veya sperm hücresine de dönüşebilmektedirler. Ancak tek başlarına yeni bir organizma oluşturamamaktadırlar, yani "totipotent" değillerdir. ${ }^{16}$ Fetal kök hücre çalışmalarında da embriyonik kök hücre çalışmalarında olduğu gibi etik sorunlarla karşılaşılmaktadır. ${ }^{11}$

\section{Erişkin Kök Hücreleri}

Erişkin ya da postnatal kök hücreler olarakta isimlendirilen bu hücreler multipotenttir ve belirli tip hücrelere dönüşebilme potansiyeline sahiptirler. Bulundukları dokuda ömür boyu çoğalırlar ve doku hasarı olduğu durumlarda rejenerasyon sağlamaktadırlar. Sınırlı diferansiye olma kapasitelerine rağmen belirli hücre tiplerine dönüşebilmektedirler. ${ }^{14}$ Kişiden alınan hücrelerin yine aynı kişide kullanılarak (otolog), bağışıklık sistemi uyum sorunu yaratmaması da postnatal kök hücrelerin avantajlarından biri olduğu belirtilmektedir. ${ }^{9}$ Embriyonel kök hücre çalışmalarının etik sorunlar ortaya çıkarması nedeni ile araştırmacılar postnatal kök hücre çalışmalarına yönelmişlerdir. ${ }^{12,14}$

İnsan vücudunda en fazla erişkin kök hücresinin bulunduğu yer kemik iliği olmasına rağmen beyin dokusu, kemik iliği, kordon kanı, kan, iskelet kası, deri, sindirim sistemi, diş, göz ve pankreasta da erişkin kök hücreleri tespit edilebilmiştir. ${ }^{3,6,9,11,13,17}$ Göbek kordonu kesilip bebek ayrıldıktan sonra ilk yarım saat içerisinde anneden ayrılan plasenta ve kordon kanı da yetişkin kök hücreler için önemli bir kaynaktır. Bu hücreler yetişkin vücudundaki hücrelere göre daha erken bir dönemde elde edildiklerinden diğer yetişkin kök hücrelere göre kullanım açısından bazı avantalara sahiptirler. ${ }^{4}$

\section{DENTAL KÖK HÜCRELER}

Diş dokularına ulaşmanın kolay ve daha zahmetsiz olması, etik ve yasal sınırlara takılmaması nedeni ile dental kök hücreler araştırmacıların ilgisini çekmiştir. Dental kök hücre çalışmalarında ortodontik amaçı çekilen dişler, çekimi gereken 20 yaş dişleri, supernumerer dişler, ortognatik cerrahide atılan alveol kemik parçaları ya da hayatın doğal akışında zamanı geldiğinde düşen süt dişleri kullanılmıştır. ${ }^{17-19}$ Dental kaynaklı kök hücre çalışmaları 2 temelde devam etmektedir. Birincisi dental kaynaklı kök hücreler ile dental dokuların rejenerasyonu, diğeri ise diğer vücut dokularının rejenerasyonudur. ${ }^{14}$

Diş gelişimi, intrauterin yaşamın 6. haftalarında başlayıp nöral krest kökenli olan mezenkim ve ektoderm kökenli epitelyal hücreler arasında meydana gelen karmaşık ve sıralı bir dizi etkileşim ile karakterize bir süreçtir. İç mine organındaki epitelyal hücrelerden ameloblastlar, dental papilladaki mezenkimal 
hücrelerden odontoblastlar farklılaşmaktadır.,18,20 Diş formasyonu iki "kök hücre" populasyonu içermektedir. Bunlar dentin-pulpa rejenerasyonuda da gerekli olan epitelyal ve mezenkimal kök hücrelerdir. Ayrıca bu epitelyal-mezenkimal etkileşimler diş gelişiminde olduğu gibi saç, tükürük bezi, pankreas gibi organların morfogenezinde de gereklidir. ${ }^{18}$

\section{Dental Epitelyal Kök Hücreler}

Embriyonel oral epitelin odongenezisi indüklemesi ile diş minesi epitelyal kök hücrelerden kaynaklanan ameloblastlar tarafından oluşturulmaktadır. Buradaki epitelyal hücreler odontogeneziste yer alan tek ektodermal kökenli hücrelerdir ve diş sürdükten sonra kaybolmaktadırlar. Sonuç olarak insan dental epitel kök hücreleri üzerinde henüz hiçbir bilgi mevcut değildir. ${ }^{21}$ Ama hayvan deneylerinde, dental epitel kök hücreler yenidoğan veya genç hayvanların üçüncü büyük azı dişlerinden elde edilip diş gelişiminde mezenkimal kök hücreler ile ilişkide olduğu gösterilmiştir. İnsan dişlerinin aksine, kemirgenlerin dişleri canlı hayatı boyunca büyür ve epitelyal kök hücre kaynağı olan servikal tomurcuk hücreleri sürekli mine üretiminden sorumludur. ${ }^{14,21}$

\section{Dental Mezenkimal Kök Hücreler}

Dental mezenkimal kök hücreler periodontal ligament, dental folikül, alveolar kemik iliği ve dental pulpanın perivasküler alanında bulunan kök hücrelerdir ve hücre tabanlı yenileyici tedavilerde potansiyel kaynak olabilmektedirler. ${ }^{18}$ Dental mezenkimal kök hücrelerin de tüm mezenkimal kök hücreler gibi kemik, kıkırdak, yağ dokusu, iskelet kası ve bağ dokusu stroması gibi mezenkimal kaynaklı dokulara diferansiye olma potansiyelleri vardır. ${ }^{14,18} 5$ farklı dental mezenkimal kök hücre tanımlanmıştır. $9,13,14,17,18,22,23$

- Dental folikül kök hücreleri [Dental follicle stem cells (DFSCS)]

- Apikal papilla kök hücreleri [Stem cells from apical papilla (SCAPS)]

- Periodontal ligament kök hücreleri [Periodontal ligament stem cells (PDLSCS)]

- Dental pulpa kök hücreleri [Dental pulp stem cells (DPSCS)]

- Düşen süt dişi kök hücreleri [Stem cells from human exfoliated deciduous teeth (SHEDs)]

\section{Dental Folikül Kök Hücreleri(DFSCs)}

İnsan DFSCS özellikle 20 yaş dişleri çekimi sonrasında rahatça elde edilebilmektedir. ${ }^{24,25}$ Mori ve arkadaşlarının yaptığı bir çalışmada 8-12 yaş arası sağlıklı çocukların ortodontik amaçlı olarak çekilen 20 yaş dişlerinin dental folikülleri kullanılmış, DFSCS'nin kemik iliği kökenli kök hücrelere(BMSCS) oranla daha yüksek proliferasyon oranına sahip olduğu gösterilmiştir. DFSCS'nin kendini yenileme ve yayılma kapasitelerinin de yüksek olduğu tespit edilmiştir. Ayrıca osteojenik kültür ortamında pasajlanan bu hücreler osteoblast benzeri hücrelere diferansiye olmuştur ve osteojenik markerlar elde edilmiştir. DFSCS'nin kemik doku rejenerasyonu için alternatif kök hücre kaynağı olabileceği belirtilmiştir. ${ }^{24}$

Yao ve arkadaşları fareye ait alt 1.moların dental folikülünde osteoblast, sementoblast, adipozitler ve nöronlara farklılaşma yeteneğinde olan kök hücreler bulunduğunu göstermişlerdir. DPSCS'nin periodontal ligament benzeri yapılara, kemik ve semente farklılaşma yeteneğine sahip olduğu düşünülüp in vivo olarak implante edildiğinde, periodontal ligament oluşturabildiğini belirmişlerdir. ${ }^{26}$ Yapılan çalışmalar sonucunda insan DFSCS'nin fibroblast, sementoblast, periodontal ligamanet ve alveolar osteoblastlara diferansiye olduğu tespit edilmiştir. ${ }^{25}$

\section{Apikal Papilla Kök Hücreleri(SCAPS)}

SCAPS 1/er 20 yaş dişlerinden ve ortodontik amaçı çekilen dişlerden elde edilebildikleri için kolay ulaşılabilir olup, kök hücre çalışmalarına alternatif olabilmektedirler. ${ }^{18}$ Sonoyama ve arkadaşları SCAPS histolojik olarak incelemişler, apikal papilla dokusunun dental pulpaya oranla daha az hücreli ve vaskülarize olmasına karşın, SCAPS'nin DPSCS'ne oranla proliferasyon yeteneklerinin daha fazla olduğunu belirtmişlerdir. DPSCS ve SCAPS'nin osteo/dentinojenik diferansiye olma potansiyelleri, BMSCS kadar iyi olduğunu ama adipojenik dönüşümlerinin zayıf olduğunu göstermişlerdir. ${ }^{27}$

Periodontal Kigament Kök
Hücreleri(PDLSCS)
1987'de McCulloch ve arkadaşları, periodontal
ligament içinde kan damarlarına bitişik küçük progen-
itör hücre topluluğu tespit etmişlerdir. Bu hücreler,
uyarıcı faktörlere karşı duyarlılığı, hızı çoğalmaları ve
küçük boyutta olmaları gibi, kök hücrelerin bazı klasik
sitolojik özelliklerini göstermiştir. ${ }^{11}$ Periodontal
ligament bağ dokusu zengin bir hücresel doku olup,

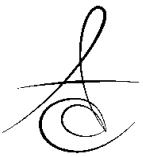


osteoblast, sementoblast, osteoklast, farklılaşmamış mezenkimal hücreler ve fibroblastlar içermektedir. PDLSCS mineralize kültür ortamında yüksek osteojenik potansiyel göstermektedir, aynı zamanda, adipositler gibi farklı hücre soylarına da diferansiye olma potansiyeline sahiptir. ${ }^{17}$

İn vitro çalışmalarda PDLSCśnin osteoblast, sementoblast ve adipozitlere diferansiye olduğu tespit edilmiştir. ${ }^{9,23}$ İ vivo farelere PDLSCS transplante edildikten sonra kemik, sement, kıkırdak ve periodontal ligament benzeri dokular oluştuğu gözlenmiştir. ${ }^{14}$

\section{Dental Pulpa Kök Hücreleri(DPSCS)}

DPSCS 20 yaş dişleri, ortodontik amaçlı çekilen 1.premolar dişler ve supernumerer dişlerden elde edilebilir. ${ }^{17,28} 2000$ yılında ilk defa Gronthos ve arkadaşları tarafından yetişkin diş pulpası kök hücresinin, odontojenik öncü popülasyonu, hücre izolasyonu, in vivo klonojenik yetenekleri, hızlı çoğalma oranları ve mineralize doku oluşturma kapasiteleri rapor edilmiştir. Bu çalışmada 19 - 29 yaş arası yetişkinlerin 3. molar dişleri kullanılmış, yetişkin diş pulpasından, klonojenik ve hızlı çoğalma popülasyonuna sahip kök hücreler izole edilmiştir. DPSCS daha sonra osteoblastların öncüleri olarak bilinen insan $B M S C S$ ile karşılaştırılmıştır. DPSCS ve $B M S C S$ in vitro benzer immünofenotipte olsalar bile, fonksiyonel çalışmalarda DPSCS'nin sadece sporadik ürediği gösterilmiş, DPSCS BMSCS'ne göre daha yüksek bir proliferasyon hızı sergilemiştir. DPSCS bağışıklığı baskılanmış farelere transplante edildiğinde, pulpa gibi interstisyel doku ile çevrili insan odontoblast benzeri hücreler ile kaplı dentin benzeri bir yapı oluşturmuştur. Bu çalışmada dentin-pulpa kompleksi benzeri yapı oluşturma yeteneğine sahip postnatal insan DPSCs yalıtılmıştır. ${ }^{29}$

Süzergöz ve arkadaşlarının yaptığı başka bir çalışmada yine 20 yaş dişi pulpası kullanılmış ve dental pulpadan izole edilen hücreler tek hücre süspansiyonu haline getirildikten sonra ekim yapılıp 72 saatlik kültür sonucu DPSCS'nin kültür ortamındaki soliter hücreleri ve hücre kolonileri gözlenmiştir. Kültürlerde kolonileri meydana getiren hücreler, DPSCS'nin kendini yenileme ürünü olarak meydana gelmekte olup, dental pulpanın kök hücre içeriği de yüksek olduğu gözlenmiştir. ${ }^{30}$

Anderson ve arkadaşları supernumerer dişten üretilen DPSCS'nin adipojenik ve osteojenik farklılaşma yeteneğine sahip olduğunu göstermişlerdir. ${ }^{28}$ DPSCS in vitro odontoblastlar, osteoblastlar, endotelisit, düz kas hücreleri, adipositler, kondrositler ve nöronlara diferansiye olabilmektedir. İn vitro DPSCS'in gelişimsel kabiliyeti sınırlı olmasına rağmen in vivo olarak daha karmaşık doku tipleri ortaya çıkabilmektedir. ${ }^{14}$

\section{DÜŞEN SÜT DİŞI KÖK HÜCRELERİ(SHEDS)}

Süt dişlerinden sürekli dişlere geçiş, daimi dişlerin gelişimi ve sürmesinin, süt dişi rezorbsiyonu ve düşmesi ile koordine edildiği, benzersiz ve dinamik bir süreçtir. Doğal bir sürecin parçası olarak düşen süt dişleri, kök hücre çalışmalarında etik değerlendirmeler açısından bir sorun olmadan kullanılabilmektedirler. ${ }^{13,18,19,22,31-33}$ Ayrıca düşen süt dişlerinden kök hücre izole etmek diğer postnatal kök hücre kaynaklarına göre daha zahmetsiz ve masrafsızdır. Çünkü invaziv ve ağrılı işlemlere gerek yoktur.,19

Kapsamlı çoğalması ve multipotensiyel farklılaşma yeteneğine sahip olan SHEDs post-natal kök hücrelerin bir bölümünü temsil edebilir. SHEDs kök hücreler için erişilebilir, ex vivo izole edilebilir ve genişletilebilir bir kaynak olacaktır. ${ }^{(-11,13}$

Son bulgular insan süt dişlerinin pulpasından mezenkimal progenitörlerin izole edildiğini ve nöronlara, adipozitlere, osteoblastlara ve odontoblastlara farklılaşabileceğini göstermiştir. ${ }^{(9,19,34)}$

İlk olarak Miura ve arkadaşları, 7-8 yaşındaki çocukların düşen süt kesici dişlerinin pulpalarından multipotent kök hücreler elde etmişlerdir. SHEDs'in sinir hücreleri, adiposit ve odontoblastlar gibi hücre tiplerine farklılaşma kapasiteleri yüksek, proliferatif, klonojenik hücre topluluğu olduğunu belirtmişlerdir. İn vivo immun sistemi baskılanmış farelere transplante edilen SHEDs'in 8 hafta sonra odontoblastlara farklılaştığı ve hidroksiapatit iskele yüzeyinde dentin benzeri doku oluşturduğunu tespit etmişlerdir. ${ }^{19}$

Mabel ve arkadaşları SHEDs'i 20 yaş dişinden hazırladıkları gözenekli biyo bozunur bir doku iskelesi ile beraber immun sistemi baskılanmış farelere 3 farklı grupta transplante etmişlerdir. 1.grupta yalnız SHEDs, 2. grupta $S H E D s$ ile insan dermal mikrovasküler endoteliyal hücreleri [Human Dermal Microvascular Endothelial Cells (HDMECS)], 3. grupta ise doku iskelesi hücresiz bir şekilde transplante edilmiştir. 3 hafta sonra SHEDs'in odontoblast benzeri hücrelere diferansiye olduğu ve doku iskelesinde morfolojik özellikleri dental pulpaya benzeyen doku oluşumu görülmüştür. Ancak SHEDs/HDMECS grubunda hücresel olarak daha zengin ve organize bir pulpa 
dokusu elde edilmiştir. ${ }^{35}$

SHEDS'in BMSCS ve DPSCS'ye oranla daha yüksek prolirefasyon hızı ve katlanarak çoğalma gösterdiği tespit edilmesine rağmen ${ }^{19}$ Suchanek ve arkadaşlarının yaptığı çalışmada SHEDs ve DPSCS aynı koşullar altında kültüre edilmiş, SHEDs'in ortalama katlanarak çoğalma zamanı DPSCS'ye oranla daha uzun ve çoğalma hızıda \%50 daha yavaş olduğu bildirilmiştir. $^{3}$

SHEDS'in vitro osteojenik, odontojenik ve adipojenik farklılaşma, in vivo olarak mineralize dokunun oluşturulması ve kapsamlı mezenkimal kök hücre markerlerinin elde edilmesi gibi BMSCS'nin sahip olduğu benzer kök hücre özelliklerini göstermektedir. 22,36

Seo ve arkadaşları 7-8 yaşlarındaki çocukların alt ve üst kesici süt dişlerini kullanılarak elde ettikleri $S H E D s$ ve $B M S C S$ ni hidroksiapatit ve seramik partiküllü trikalsiyumfosfat [Hydroxyapatite/tricalcium phosphate ceramic particle (HA/TCP)] ile karıştırarak, kritik boyutlardaki kalvarya defekti olan immun sistemi baskılanmış farelere transplante etmişlerdir. Fareler SHEDS grubu, BMSCS grubu ve hücresiz HA/TCP kontrol grubu olarak incelenmiştir. Transplantasyondan 6 ay sonra SHEDs grubunda kalvarya defekti tamamlanmış ve kemik devamlılığı tespit edilmiştir. SHEDS grubunda oluşan kemik dokunun BMSCS grubundakine oranla hematopoetik ilik elemanlarınca daha zayıf olduğu görülmüştür. SHEDs ve BMSCS'nin kemik rejenerasyon kapasiteleri benzer düzeyde olmasına rağmen hücresiz $H A / T C P$ grubunda kemik formasyonunun yetersiz olduğu tespit edilmiştir. SHEDs'in aktif yeni kemik oluşumu için osteoblast benzeri hücrelere farklılaşma yeteneğine sahip olduğu bildirilmiştir. ${ }^{32}$ SHEDs direk osteoblastlara dönüşmez ama konak osteojenik hücrelerinde osteoindüktiv bir şablon oluşturarak yeni kemik oluşumunu sağladığı tespit edilmiştir. ${ }^{18,19}$

Wang ve arkadaşları immun sistemi baskılanmış farelere subkutanöz olarak SHEDs ve DPSCS'ni seramik sığır kemiği[ceramic bovine bone( $C B B)$ ] ile beraber transplante etmişlerdir. 8 hafta sonunda SHEDs transplante edilen grupta $C B B$ etrafında yüksek mineralize ama kemik iliği elemanlarından yoksun doku rejenerasyonu görülmesine rağmen DPSCS grubunda bağ doku oranı yüksek, zayıf mineralize doku oluşumu tespit edilmiştir. ${ }^{37}$ İn vitro koşullarda hücre kültürü sonunda SHEDs'in osteojenik ve adipoenik kapasitesi DPSCS'ye oranla daha yüksek bulunmuştur. ${ }^{19,37,38} \mathrm{Bu}$ sonuca göre $S H E D$ s'in yüksek olan osteojenik diferansiyasyon kapasitesi süt dişlerinin sürekli dişlerin erüpsüyonu sırasındaki kemik formasyonuna etkilerini açıklamaktadır. ${ }^{37}$

Zheng ve arkadaşları orafasiyal kemik defektlerinin rejenerasyonunda kök hücrelerden yararlanma etkinliğini incelemek için minyatür domuz süt dişi kök hücreleri[stem cells derived from miniature pig deciduous teeth (SPD)] izole etmiştir. Domuz mandibula modellerinde kritik boyutlarda kortikal kemik defektleri oluşturulmuş, çalışma için 3 grup belirlenmiştir. 1. grupta $S P D$ beta trikalsiyum fosfat[Beta Tricalcium Phosphate ( $\beta$-TCP)] iskele ile beraber 7 gün kültüre edildikten sonra kritik boyutlu kortikal kemik defektlerine transplante edilmiş, 2. grupta sadece $\beta$ TCP transplante edilmiş, 3. grup ise tedavi edilmeden bırakılmıştır. 4 haftalık bilgisayar tomografi takip sonucunda $S P D / \beta-T C P$ ile tedavi edilen grupta kemik rejenerasyonu ve yeni kemik ile defekt köprüleme formasyonu görülmüştür. $B$-TCP grubunda kemik defektinde net olmayan kemik formasyonu ile kısmi bir köprüleme tespit edilmiştir. Tedavi edilmeyen kontrol grubunda ise kemik defektin devam ettiği ve kemik rejenerasyonunun zayıf olduğu belirtilmiştir. Özellikle büyük hayvan modelinde yapılan bu pre-klinik ön çalışma, insan orafasiyal defektlerinin rekonstrüksiyonunda kök hücre destekli tedavi için öncü olmuştur. ${ }^{33}$

Nöral gelişim potansiyeli tespiti için SHEDs immun sistemi baskılanmış fare beynine enjekte edilmiş ve 10 gün sonra SHEDs'in fare beyninde hayatta kaldığı tespit edilmiştir. SHEDs'in nöral hücre morfolojisine diferansiyasyonu bildirilmiştir ve nöral indüksiyon şartlarında kültüre edildiğinde erken nöronal markerlar tespit edilmiştir. ${ }^{(19)}$ Wang ve arkadaşları sıçan modelinde Parkinson hastalığının hafifletilmesinde SHEDs'in terapötik etkinliği incelenmişlerdir. SHEDs'in vitro nöral kök hücreler için optimize edilmiş bir ortamda nöral doku benzeri form oluşturacak şekilde indüklenebilmiştir. ${ }^{22,39}$ İnkübasyon sonucunda SHEDs spesifik dopaminerjik nöronlar bulunan hücre popülasyonuna diferansiye olduğu tespit edilmiştir. Bu indüklenen hücreler Parkinson oluşturulmuş sıçanlara transplante edildikten sonra davranışsal bozuklukların kısmen düzeldiği tespit edilmiştir. Bu veri SHEDs'in potansiyel olarak nöral krest hücrelerden kaynaklanan Parkinson hastalığı tedavisi için doğum sonrası kök hücrelerin optimal bir 
kaynak olabileceğini göstermektedir. ${ }^{39}$

Moleküler test sonuçları, SHEDS'in laboratuvar ortamında sinir benzeri hücrelerin özelliği olan kapsamlı bir gen ve protein dizisi göstererek sinir hücrelerine dönüşebileceğine kanıt sağlamaktadır. 18,19,22 SHEDs hücreleri, çok çeşitli sinirsel hastalıkların ve yaralanmaların otolog transplantasyonu için yeni bir seçenek olarak düşünülebilmektedir. ${ }^{22}$

Kök hücreler kendi orjinlerinden gelen hücrelere diferansiye olma eğilimindedirler. Diş hücreleri nöral krest kökenlidir ve in vivo nöral hücrelere diferansiye olabilirler. Bu sebeple DPSCŚnin diğer mezenkimal kök hücrelerine göre nöral farklılaşma için daha büyük bir potansiyele sahip olduğu düşünülmektedir. ${ }^{(38)}$ Ancak SHEDs ve DPSCS aynı kökenden gelmelerine rağmen diferansiyel eğilimlerinde farkllıklar görülmüştür. ${ }^{19,37,38}$ SHEDs'nin DPSCS'ne göre daha yüksek pluripotent marker elde edilerek kendi kökenlerinden gelen hücrelere diferansiye olma eğilimlerinin daha fazla olduğu tespit edilmiştir. Buna rağmen DPSCS'de daha fazla nöroepitelyal kök hücre markerleri bulunmuştur. Bu nedenle nörolojik hastalıklar için DPSCS kullanımını vurgulanmıştır. ${ }^{38}$

DFSCS de, SHEDS gibi diş kaynaklı nöral krest kökenli hücreler olup, bu iki hücre standart kültür ortamında farkı hücre morfolojileri göstermişlerdir. SHEDS ve DFSCS nöron benzeri hücrelere diferansiye olmalarına rağmen, aynı diferansiyel potansiyelde değillerdir ve bu hücrelerden farklı nöronal hücre markerları elde edilmiştir. ${ }^{25}$

Ishkitiev ve arkadaşları ektomezenkim kökenli olan SHEDS ve DPSCS 'in endoderm kökenli olan hepatosit benzeri hücrelere diferansiye olduğunu göstermişlerdir. ${ }^{40}$ SHEDS ve DPSCS nöral hücrelere, osteoblast, adipozit ve kondrositlere diferansiye olabilir. ${ }^{38}$ SHEDs osteoblastlar, odontoblastlar, adipositler, kondrositler, ve hepatositler gibi çeşitli hücre tiplerine (in vitro ve in vivo) diferansiye olma yeteneğine sahip yeni bir kök hücre nüfusu olarak kabul

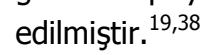

\section{Süt Dişi Bankacılığı}

SHEDS'nin bir çok postnatal kök hücre kaynağına göre yüksek olan diferansiyasyon ve çoğalma kapasitesi süt dişi bankacilığını gündeme getirmiştir. ${ }^{41,42}$ Süt dişlerinin doğal bir süreç içinde eksfoliye olması, çocuk ve aileler için basit ve ağrısız bir şekilde elde edilmesi, kordon kanı saklama yöntemine göre daha az maliyetli olması, SHEDS'nin embriyonik kök hücreler gibi etik sorunlar yaratmaması ve aile yakınları arasında da kullanılabilir olması kök hücre bankacılığının avantajlarından birkaçı olarak sayılabilmektedir. Süt dişi bankaclığı açısından tüm süt dişleri aynı potansiyelde değildir. Genellikle herhangi bir patolojisi olmayan süt kesici ve kanin dişler tercih edilmektedir. Süt molar dişler ağızda daha uzun süre kaldıkları için köklerde obliterasyon ve pulpa dokusunun canlılığında azalmalar görülebilmektedir. Ama ortodontik nedenlerle düşme zamanından önce çekilen süt molar dişlerde süt dişi bankacılığı açısından uygun olduğu düşünülmektedir. ${ }^{41}$ Ülkemizde kordon kanı bankacılığı gibi süt dişi bankacılığı yapan birkaç firma bulunmaktadır.

\section{SONUÇ}

Bu güne kadar yapılan çalışmalar düşmüş süt dişlerinden elde edilen kök hücrelerin (SHEDS) çeşitli dokular oluşturma kapasitelerinin yüksek olduğunu göstermiş, kolay ulaşılabilmeleri ve elde edilmeleri nedeni ile de kök hücre çalışmalarında tercih sebebi olabilecekleri bildirilmiş̧ir. Ancak çok fazla geçmişe sahip olmayan bu hücreler üzerinde daha ileri çalışmalara intiyaç duyulmaktadır.

\section{KAYNAKLAR}

1. Verfaillie CM, Pera MF, Lansdorp PM. Stem Cells:Hype and Reality. Am Soc Hem Educ Program. 2002;369-91

2. Sağsöz H, Ketani MA. Stem Cells. J Fac Vet Med Univ Dicle 2008;129-33

3. Suchanek J, Visek B, Soukup $T$, Sked $M$, Ivancakova R, Mokry J, Aboul-Ezz EHA, Omran A. Stem Cells from Human Exfoliated Deciduous Teeth - Isolation, Long Term Cultivation and Phenotypical Analysis. Acta Medica(Hradec Kralove) 2010;53:93-9

4. Şahin F, Saydam G, Omay SB. Stem Cell Plasticity and Stem Cell Treatment in Clinical Practice. Turk J Hematol Oncol 2005;1-15

5. Silver LM. The Proteus Effect: Stem Cells and Their Promise for Medicine. Reviewed by Parson AB. Stalking Life's Second Secret. Autumn Books Nature 2004;431:905-7.

6. Güneş AM. Stem Cell Plasticity and Uses in 
Medicine. J Pediatr Date 2005; 71/36-42

7. Kansu E. Current Concepts in Stem Cell Biology and Plasticity. Hacettepe Med J 2005;36:191-197

8. Karaşahin T. Embryonic Stem Cells. J Fac Vet Med Univ Erciyes 2012; 9: 65-71

9. Lozano $F J R$, Insausti $C L$, Iniesta $F$, Blanquer $M$, Ramírez MC, Meseguer L, Meseguer-Henarejos AB, Marín N, Martínez S, Moraleda MJ. Mesenchymal Dental Stem Cells in Regenerative Dentistry. Med Oral Patol Oral Cir Bucal 2012;17:1062-7

10. Snykers $S$, Kock JD, Rogiers $V$, Vanhaecke T. In Vitro Differentiation of Embryonic and Adult Stem Cells Into Hepotocytes:State of the Art. Stem Cells 2009;27:577-605

11. Mudda JA, Bajaj M. Stem Cell Therapy:A Challenge to Periodontist . IJDR 2011;22/1 132-9

12. Kara MA. About Stem Cell Research. Klin J Med Ethics Law History 2004; 12:121-31

13. Telles PD, Machado MAAM, Sakai VT, Eduardo J. Pulp Tissue from Primary Teeth: New Source of Stem Cells. J Appl Oral Sci. 2011;19:189-94

14. Ulmer FL, Winkel $A$, Kohorst $P$, Stiesch M. Stem Cells -Prospects in Dentistry. Schweiz Monatsschr Zahnmed 2010;120 10

15. O'Donoghue K, Fisk NM . Fetal Stem Cells:Best Practice and Research. Clin Obstet Gynecol 2004; 18:853-75

16. Campagnoli $C$, Roberts IA, Kumar S. Identification of Mesenchymal Stem/Progenitor Cells in Human First-Trimester Fetal Blood, Liver, and Bone Marrow. Blood 2001; 98: 2396-402.

17. You-Young JO, Lee HJ, Kook SY, Choung HW, Park JY, Chung JH, Choung YH, Kim ES, Yang HC, Choung $\mathrm{PH}$. Isolation and Characterization of Postnatal Stem Cells from Human Dental Tissues. Tissue Eng 2007;13: 4

18. Brar GS, Toor RSS. Dental stem cells: Dentinogenic, Osteogenic and Neurogenic Differentiation and Its Clinical Cell Based Therapies. Indian J Dental 2012;23: 3

19. Miura M, Gronthos S, Zhao M, Lu B, Fisher LW, Robey PG, Shi S. SHED:Stem Cells from Human Exfoliated Deciduous Teeth. Proc Natl Acad Sci 2003;100: 5807-12

20. Sharpe PT. Neural Crest and Tooth Morphogenesis. Adv Dent Res 2001;1:4-7

21. Bluteau G, Luder HU, Bari CD. Stem Cells for Tooth Engineering. Eur Cells Mater 2008;16: 1
22. Nourbakhsh N, Soleimani M, Taghipour Z, Karbalaie K, Mousavi S, Talebi A. Induced in Vitro Differentiation of Neural-Like Cells from Human Exfoliated Deciduous Teeth-Derived Stem Cells. Int J Dev Biol 2011;55: 189-95

23. Seo BM, Miura M, Gronthos S, Bartold PM, Batouli $\mathrm{S}$, Brahim J. Investigation of Multipotent Postnatal Stem Cells from Human Periodontal Ligament. Lancet 2004;10-16;364:149-55

24. Mori $G$, Ballini $A$, Carbone $C$, Oranger $A$, Brunetti $G$, Benedetto AD. Osteogenic Differentiation of Dental Follicle Stem Cells. Int. J. Med. Sci 2012;9:480-7

25. Morsczeck C, Vollner F, Saugspier M, Brandl C, Reichert T.E, Driemel O. Comparison of Human Dental Follicle Cells and Stem Cells from Human Exfoliated Deciduous Teeth After Neural Differentiation in Vitro. Clin Oral Investig 2010;14: 433-40.

26. Yao $S$, Pan F, Prpic V, Wise GE. Differentiation of Stem Cells in the Dental Follicule. J Dent Res 2008; 87: 767-71.

27. Sonoyama W, Liu Y, Yamaza T, Tuan RS, Wang S, Shi S. Characterization of the Apical Papilla and Its Residing Stem Cells from Human Immature Permanent Teeth: a Pilot Study. J Endod 2008; 2/34: 166-71.

28. Huang AHC, Chen YK, Lin LM, Shieh TY, Chan AWS. Isolation and Characterization of Dental Pulp Stem Cells from a Supernumerary Tooth. J Oral Pathol Med 2008;37: 571-4

29. Gronthos S, Mankani M, Brahim J, Robey PG, Shi S. Postnatal Human Dental Pulp Stem Cells in Vitro and in Vivo. PNAS 2000;5: 25

30. Süzergöz $F$, Erdem AP, Sepet $E$, Bektaş $M$, Yalman $N$, Gürol AO. A Pilot Study on the Isolation of Dental Pulp Stem Cells, Potential of Forming Colonies and Defining the Content of Stem Cells. Turkiye Klinikleri J Med Sci 2009;29:128-33

31. Kerkis I, Caplan AI. Stem Cells in Dental Pulp of Deciduous Teeth. Tissue Eng Part B 2012/18:2

32. Seo BM, Sonayama W, Yamaza T, Coppe C, Kikuiri T, Akiyama K. SHED Repair Critical-Size Calvarial Defects in Mice. Oral Dis 2008;14:428-434

33. Zheng Y, Liu Y, Zhang CM, Zhang HY, Li WH. Stem Cells from Deciduous Tooth Repair Mandibular 
Defect in Swine. J Dent Res 2009;88:249

34. Aydın A, Berbercan P. Biyomühendislik Esasları ile Diş Oluşturulmasına Yönelik Yaklaşımlar. SÜ Dişhek Fak Derg 2010;19:99-114

35. Cordeiro MM, Dong Z, Kaneko T, Zhang Z, Miyazawa M, Shi S. Dental Pulp Tissue Engineering with Stem Cells from Exfoliated Deciduous Teeth. JOE 2008;34: 8

36. Yamaza T, Kentaro A, Chen C, Liu Y, Gronthos S, Wang S. Immunmodulatory Properties of Stem Cells from Human Exfoliated Deciduosus Teeth. Stem Cell Research Therapy 2010;1: 5

37. Wang X, Sha XJ, Li GH, Yang FS, Ji K, Wena LY. A Comparative Characterization of Stem Cells from Human Exfoliated Deciduous Teeth and Dental Pulp Stem Cells. Archives of Oral Biology 2012; 57:1231-40

38. Govindasamy V, Abdullah AN, Ronald VS, Musa S, Aziz ZACA, Zain RB. Inherent Differential Propensity of Dental Pulp Stem Cells Derived from Human Deciduous and Permanent Teeth. JOE 2010;36: 9

39. Wang J, Wang $X$, Sun Z, Wang X, Yang H, Shi S. Stem Cells from Human Exfoliated Deciduous Teeth Can Differentiate into Dopaminergic Neuronlike Cells. Stem Cells Deve 2010;19:1375-83.

40. Ishkitiev N, Yaegaki K, Calenic B. Deciduous and Permanent Dental Pulp Mesenchymal Cells Acquire Hepatic Morphologic and Functional Features in Vitro. J Endod 2010;36:469-74

41. Arora V, Arora P, Munshi AK. Banking Stem Cells from Human Exfoliated Deciduous Teeth: Saving for the Future. Journ Clinic Pediat Dent 2009;33: 4

42. Perry BC, Zhou D, Wu X, Yang FC, Byers MA, Chu TM. Collection, Cryopreservation, and Characterization of Human Dental Pulp-Derived Mesenchymal Stem Cells for Banking and Clinical use. Tissue Eng Part C Methods 2008;4: 149-56.

\author{
Yazışma Adresi \\ Dt. Gülcan ÜNSAL \\ İstanbul Üniversitesi \\ Diş Hekimliği Fakültesi \\ Pedodonti Anabilim Dalı \\ Kat:3 Çapa/FATİH/İSTANBUL \\ İş tel:0212 4142020 / Dahili (30317 veya \\ 30400) \\ Cep tel:05065168355 \\ e-mail: gulcansahinunsal@gmail.com
}

